\title{
Public Policies and Public Library-Emergent Literacy Relationship in the USA
}

\author{
Amerika Birleşik Devletleri'nde Kamu Politikaları ve Halk \\ Kütüphanelerinin Erken Okuma-Yazma İşlevi ile İlişkisi
}

Arif YILMAZ*

\begin{abstract}
In the USA, last decade witnessed a huge interest in children's early literacy development. All public agencies, as a part of public support to education, started to align their visions and missions to contribute to this sort of interest along with the support of the federal government. The Federal Government supported this growing interest with several acts and hence, all public agencies including ALA and other library associations revised their mission statements. Public libraries, with their special feature of the equal and free access to the public they serve, were considered to be one of the most appropriate places to support children's early literacy development. In that context, a public library was chosen in terms of its staffs' perceptions of early literacy and their services to the clientele. The study results revealed that the library staff believe in the importance of children's early literacy development, and prepare programs to support it, although they have some constraints such as shortage of funds and difficulties in reaching all the people in the community.
\end{abstract}

Keywords: Public libraries, Public policy issues, Literacy, Preschool children

\section{Öz}

Son on yıl, Amerika'da çocukların erken okuma-yazma gelişimleri üzerine büyük bir ilginin odağı oldu. Bütün kamu kurumları eğitime destek çerçevesinde görev ve vizyon durumlarını Federal hükümetin de desteğiyle büyüyen bu ilgiye destek olabilmek amacıyla yeniden değerlendirmeye aldılar. Federal hükümet çocukların erken okuma-yazmaya olan ilgilerinin desteklenmesini çeşitli kanunlarla destekledi ve Amerikan Kütüphane Derneği başta olmak üzere diğer kütüphane dernekleri ve ilgili bütün kamu kurumları görev tanımlarını yenilediler. Bununla beraber, halk kütüphaneleri, toplumun her kesiminden insanlara açık ve ücretsiz erişim sağlayan bir kurum olarak, çocukların erken okuma-yazma gelişimini destekleyebilecek en önemli kurumların başında gösterildi. Bu

"Dr.; Hacettepe University, Faculty of Education, Division of Pre-School Teaching, Beytepe, Ankara (arif@hacettepe.edu.tr) 
bağlamda bu çalışmada, bir halk kütüphanesinin personelinin konuya olan bakış açısı ve bu konuyla ilgili olarak verdikleri hizmetler değerlendirildi. Çalışmanın sonuçlarına göre seçilen halk kütüphanesinin personeli her ne kadar para sorunları başta olmak üzere toplumun her kesimine erişmede zorluklarla karşılaşsalar da konunun öneminin farkında olup bu bağlamda hizmet vermeye çalışmaktadırlar.

Anahtar sözcükler: Halk kütüphaneleri, Kamu politikaları konuları, Okuma-yazma, Okul öncesi çocuklar

\section{Introduction}

In recent years there has been a growing interest in children's early literacy development. This concern is raised by two main reasons; the changing demographic structure of the U.S. and parents' shifting demands, for example they want their children to be ready for first grades and to be able to read when they enter into the grade schools. Researchers have found that early literacy development has a strong correlation with children's future academic achievement programs (Bowman, Donovan and Burns, 2001; Shonkoff and Phillips, 2000). Literacy development in the U.S. has become more complex because of the great influx of immigrant children with Limited English Proficiency (LEP) into American schools, and children living in poverty.

There are several institutions and several individuals contributing to children's early literacy development, including teachers in elementary schools, kindergartens, preschools, and day care centers; care providers at Head Start centers; librarians at public libraries; parents or other care providers in children's homes. Our particular interest is how children's early literacy development can be enhanced at public libraries.

Because of their general literacy and information role in the community structure, public libraries play a special role in providing appropriate literacy practices. Libraries are places that are free to everyone regardless of race, ethnicity, culture, language, or age. They are open to public 7 days a week. Because low socio-economic and minority children are at risk in terms of early literacy development and because books and literacy materials are less accessible to poor parents and their children, public libraries' role as a free, public provider becomes even more vital to meeting this population's demands for literacy materials and support. Hence, because of their primary purpose of facilitating literacy development in citizens and because they are open to all, they are ideal sites for the development of young children's literacy. In the societal context, today, public libraries can have leading roles in implementing emergent literacy programs. In order to serve the community more effectively, libraries need to be investigated as to whether their programs are effective or not as well as what kind of difficulties they encounter (institutional or professional) in the planning or implementing stage of these literacy programs. In this study, the factors (institutional and professional) which one public library branch encounters during the implementation of emergent literacy programs were examined. 


\section{The Nature of Emergent Literacy}

According to Sulzby (1991, p.728), emergent literacy is "the reading and writing behaviors that precede and develop into conventional literacy." Emergent literacy deals with the beginning oral and writing stages of language development including reading readiness that takes place from children's birth to their conventional reading and writing stage that typically begins in first grade. According to Roskos and Neuman (1994, p.79), the emergent reader:

"knows what a book is; holds the book correctly; recognizes front and back covers of the book; turns pages from front to back; reads a story from pictures; reads a favorite book from memory; sequences a story; recites rhymes and sings songs; makes predictions about story content based on illustrations and title; knows spoken word can be written down in print; can name some letters."

Similarly, according to the authors, the emergent writer:

"uses scribbles and drawings to communicate ideas; gestures or role plays while drawing or writing as another means of communication; experiments with leftto-right and right-to-left writing; is developing a growing awareness of what is a 'word'; imitates making signs and lists like the 'grownups'; pretends to read his or her own scribing or letters; often draws illustrations and adds the 'text'" (Roskos and Neuman, 1994, p.79).

Focus on children's emergent literacy skills should be observed in home settings, day care settings, and school settings. A purpose of Head Start schools and other public and private preschools, kindergartens, and day care centers has always been to enhance literacy of young children. Currently, the emphasis on the importance of early reading to later school success has caused many such educational settings to improve their literacy instruction. Traditionally, emergent storybook reading and emergent writing in the home have been seen as the major site of literacy development (Sulzby, 1991), however because so many children are in preschool situations and because so many families have LEP, more emphasis is being put on the need for literacy development at out-of-the-home settings.

Recent literature on the relationship between storybook reading or story telling and children's emergent literacy development shows that there is a definite connection between them (Koehnecke, 2000; Pankey, 2000; Phillips, 1999). Anderson and Matthews (2000) find that low income families' children did not do well reading story books compared to middle-class families' children. Probably because of the lack of opportunity in accessing print materials, absence of necessary home or school environment where children's literacy skills are supported, and absence of necessary parenting skills to foster these skills. Another study shows that early connections between home, language, and emergent literacy have significant influence on the later reading achievement of low income families' children (Storch and Whitehurst, 2001). Yet another longitudinal study (Senechal and LeFevre, 2001) indicates that middle- 
class children with highest exposure to reading aloud at home demonstrate advantages in spelling, decoding, and alphabet knowledge. All this research agree that children's early experience with literacy no matter how (reading aloud, storytelling, etc), or where (home, school, daycare) have tremendous effect on their later school readiness and achievement.

\section{Literacy Development and National Goals and Legislation}

When "Goals 2000: Educate America Act" became a federal law in 1994, the first goal was "By the year 2000, all children in America will start school ready to learn" (Department of Education, 2007a). This act became the cornerstone of the growing interest in and focuses on children's early literacy development. In 1998, the Reading Excellence Act (REA), signed by the President, allowed hundreds of million dollars to be made available expressly for the purpose of improving children's literacy skills. This was an indicator of the Federal Government's determination on the issue (Department of Education, 2007b). These federal mandates put in force steps requiring various levels of governmental and non-governmental organizations to take actions regarding the issue of children's literacy development. With "No Child Left Behind" the new education law (No Child Left Behind Act, 2001), development of children's early reading and writing skills gained more attention and was a focal point of interest by both politicians and researchers. These federal mandates put in force steps requiring various levels of governmental and non-governmental organizations to take actions regarding the issue of children's literacy development.

As a result, all over the nation, a number of early literacy or family literacy programs were initiated or their implementation was strengthened at libraries. In 1998, for example, "21st century Literacy" appeared as one of the American Library Association's five key action areas in their long-term action policy statement (American Library Association, 2007). Then, in 2000, the Public Library Association started an Early Literacy Initiative in collaboration with National Institute of Child Health and Human Development (NICHD) (Public Libraries Association, 2007).

The Association for Library Service to Children (ALSC), a division of American Library Association (ALA) together with The Prudential Foundation sponsored the "Born to Read" program for three-year-old-children (The Association for Library Service to Children, 2007). In 2002, states were encouraged to pursue five year plans under Library Services and Technology Act. These initiatives serve as exemplars of the state level focus on the issue of children's literacy development. For example, the State of Connecticut's Library Services and Technology Act (2nd five year plan) makes sure that all children in Connecticut have access to quality library services. This act requires implementation of an emergent literacy initiative which put public libraries into the front line of application of the initiative (Connecticut State Library, 2007). Rhode Island READS project (Morton, 2007) is another state based early literacy initiative which aims to increase literacy skills of preschool through 6th grade children. The fact is that a federal level of support for literacy development of children has shown an effect on 
governmental and non-governmental organizations, especially on library associations, and encouraged these agencies to take immediate actions to better serve the literacy needs of young children.

\section{Emergent Literacy and Public Libraries}

It is an interesting fact that there is no existing literature that establishes a link between libraries and children's emergent literacy development in educational research except for the studies of Teale (1995). Teale is a reading and English professor at University of Illinois-Chicago who focuses on the impact of public libraries on emergent literacy. Teale (1995) points out that libraries and librarians, working cooperatively with family literacy programs or other community wide programs, may serve children in their homes or in libraries. Teale also suggests that libraries can employ special programs that promote children's early literacy development or they may distribute materials to be used in homes or child care settings.

Likewise, lack of research on this emergent literacy development through community libraries has been addressed by several researchers (Dowd, 1997; Kinney, 1996). Dowd states that emergent literacy is not an interest area for the library community and calls for research on this problem; she even provides a detailed design of an experimental study that can be used to investigate the matter. There are, however, few studies done by researchers in library science. McKechnie (1996), for example, investigated 4 year old girls' library usage habits through an ethnographic study. She observed and tape recorded their library visits with their mothers and conducted interviews with the mothers who also kept diaries regarding their children's involvement with library materials and other library services. Results of this study show that public libraries have significant impact on the children's reading development through providing print-rich environments. Another study (Nespeca, 1995) focuses on urban Head Start children's parents' handling strategies of their children's emergent literacy skills and utilization of public library in this process. The study reveals that parents do not use many of the library services because of lack of transportation or time, and fear of damaging books and have to pay for them in return. The parents also express a demand for library outreach programs and workshops about using the libraries. This is a thought-provoking study, because it documents low-income families' economical and educational shortages as a reason that prevents them from using library services effectively when they are the ones who should be the main users of public libraries.

In this context, library outreach programs gain essential importance serving those who do not have the opportunity to use the libraries on site. The fact that library outreach programs are important for the people living in public housing homes is clearly stated in Kinney's (1996) Ph.D. thesis and this naturalistic inquiry reveals that story mobile service has significant positive effects on children's emergent literacy skills in these homes. Another quantitative study, also, supports positive effects of a library outreach program. Fehrenbach, Hurford, Fehrenbach, and Brannock (1998) design an experimental 
study to evaluate a library outreach program's effectiveness on preschool children's emerging literacy skills. 29 white, middle-class children participated in the study. The results of the study show that children exposed to library outreach training demonstrated higher emergent literacy and pre-reading skills and were able to read more words correctly. The author, also, suggests that "librarians could work with schools of education in the development and implementation of programs promoting literacy in early childhood."

In the light of the discussion above, the research questions identified for the present study are:

$\diamond$ How do children's librarians perceive children's emergent literacy development and provide services for this clientele?

$\diamond \quad$ What is the profile of the clientele of the public library and what kind of services are provided in terms of emergent literacy development?

\section{Research Design}

In order to address these research questions, a qualitative research design was employed in the study. According to Patton (1985, cited in Merriam, 2001, p.6) "Qualitative research is an effort to understand situations in their uniqueness as part of a particular context and interactions there". Unlike quantitative research designs, qualitative designs allow the researcher to explore "understanding the meaning people have constructed" (Merriam, 2001, p.6). More specifically, a descriptive case study which Merriam (2001, p.19) describes as "A case study design is employed to gain indepth understanding of the situation and meaning for those involved" was conducted. Developing a descriptive case study, the author aimed to understand that in their specific context, how children's librarians constructed their perceptions about children's literacy development and how this construction functions in serving to children from different socio-economic backgrounds, and how the profile of the clientele affects their role in helping children's literacy development in this particular context.

The study took place in a Midwestern county with a population of approximately 120.000. In county library system, there are two public libraries located 10 miles apart from each other. The main branch is located in a city where 70.000 people live. The city has a large university which is the main economic contributor to the city as well as the county. According to Census 2000 statistics (Census, 2000) $85 \%$ of the total population is white, $5.3 \%$ is Asian, $2.5 \%$ is Latino and $4.2 \%$ is African-American. Poverty level of the county was $12 \%$ and this level even goes higher for under the age of 18 year old children, $14.1 \%$. Approximately 15.000 children were enrolled in $\mathrm{K}-12$ schools in 1999. $30 \%$ of these children were eligible for free or reduced fee lunch program (CAPE, 2007). These data show that, at-risk children's number is high enough not to be ignored. These children should be ready for school and public libraries may play a vital role in this process. 


\section{Data Collection}

In order to explore in depth the views of the participants about their experiences, semistructured interviews and observations were used. Merriam (2001, p. 74) suggests that a semi-structured interview is more flexible to let the researcher respond to the spontaneous situation, to the participants' emerging worldview, and to new or unpredictable ideas on the topic. Merriam (2001, p.96) also, states that observations are important to provide "extra knowledge of the context or to supply specific incidents, behaviors that can be used as reference points to support interview data".

Two interviews were conducted with the participants on the site. Each of these interviews lasted 40-45 minutes and were audio-taped and then transcribed verbatim. Some of the interview questions are; what is the library's role in developing young children's literacy competencies, what services are available for children with limited English proficiencies, or ethnically diverse children, how is your department meeting the literacy development needs of young children. The author made observations at the site several times. During the observations, it was focused on the content of the programs developed for the clientele and the profile of the clientele using the library.

\section{Participants and Setting}

According to Merriam (2001, p.61) "to solve qualitative problems, such as discovering what occurs, the implications of what occurs, and the relationships linking occurrences, the most appropriate sampling strategy is non-probabilistic-the most common form of which is called purposeful". Using purposive sampling, two participants working in the public library which is located at the heart of downtown were selected. One of the participants, Kelly (names in the study are pseudonyms), had an administrative position in the library while the second participant, Emily, was working solely as a child librarian in the children's department.

The library has two floors and half of the first floor is devoted for children's books and services. My first impression is that there were a lot of materials, such as books, CD's, videos, audio tapes, magazines, and toys for children. Another striking feature of the department is the relaxing and inviting environment created for people visiting the library. Most of the furniture and bathrooms in the area are designed in children's size. In the area there are several divisions such as Homework Center, Children's Program Room, Parent's Resource Room, and Preschool Exploration Area. Each of these areas is used often by the clientele or the librarians. There were six children's librarians when the study was conducted.

\section{Data Analysis}

In analyzing the data, the transcriptions of the data collected through interviews were extensively and repetitively read. I prepared a summary of the most important aspects for each interview question. Then, the author generated basic themes and categories by 
constantly looking for similarities and parallels in the data. These categories helped me understand the participant's ideas and practices about emergent literacy. In addition to this, it was looked for logical groupings and links among the categories. The categories and themes emerging from the participant's interview data were conceptualized as a whole. In the following part, the findings of the study are presented.

\section{Findings and Discussion}

In this section, the main themes that emerged from the data will be discussed. Four main themes that emerged are: the childrens' librarian's perceptions of libraries' role in developing emergent literacy skills, profile of the clientele, programs, and constraints. Before starting to explain the themes, a brief background information about participants is given at the following paragraphs.

Kelly has been working in the library for more than 30 years and she has been serving as the head of the children's department since 1976. She started her carrier as a fine arts librarian in an apprenticeship library in Kentucky. Then, she came to IU to receive a degree and started to work in the children's department. After a conference she attended, she started to read about early childhood education to find out how libraries and librarians may serve children better. She kept on reading for a while and decided to start a library program for two-year old children called "first friends". And then in early 80's, another program called "Early Literacy Skill Project" (a five year program) was presented by Children's Department under the supervision of Kelly.

Emily who has been working for 18 years in the Public Library Children's Department graduated from secondary education department and worked as an English teacher and speech and drama teacher in a junior high school. She was also supervising the library and became interested in libraries and decided to get an advanced degree in library science rather than English or drama. In early 70's she became a media specialist and worked as a secondary school librarian for 3 years and high school librarian for two years. The she moved to Bloomington where school media jobs were not available then. She accepted a position in the Children's Department of the public library. She felt that she had an affinity for working with young children and she enjoyed it. She points out that, this job gave her a chance to storytelling and felt that storytelling fed her drama background. She thinks that it was an accidental, a serendipitous happy accident.

\section{Perceived role of Libraries in the development of Emergent Literacy}

Emily thinks that libraries are very important institutions in raising the awareness of parents toward reading and in providing services for especially low income families. According to her, some of the responsibilities of library are to attract the interest of reluctant readers as well as providing resources for children already interested in reading, to have parents value reading more and to promote the services provided by the library. In terms of raising the awareness of parents, library programs may become 
a role model for parents who want to help their children at home with their literacy skills. Kelly notes that it is very important to get parents involved in their children's literacy development and to change their attitudes in favor of the importance of reading in a child's life. Pointing out the influence of early experiences on a child's literacy skills, the library attempts to create an environment where children interact with adults verbally or interact with the materials to reinforce concept and vocabulary development.

Both participants agree that the library might contribute to the development of children's emergent literacy by providing rich circulation materials as well as on site programs. In that sense, the department has a toy collection, and an audio collection which is focused on audio cassettes and CD's because the librarians perceive that listening skills are important as a pre-reading skill. They also provide materials for parents, because the librarians believe that parents need to be supported, too. They believe in the importance of networking with the parents and the community. So, they arrange meetings for parents to meet representatives of the organizations in the community. In general, the librarians' and Department's perception of library's role in the development of children's emergent literacy skills is embedded in their services.

\section{Profile of the Clientele}

Both participants reported that the main clientele of children's department are children from birth up through sixth grade, and adults who take care of those or have interactions with those children. Kelly reported that low income families are using the library more compared to upper-middle class white families. However, she points out the composition of the town and its influence on the clientele profile. She reports that since Bloomington is a college town, there are many graduate student families who are considered to be low income families at this stage since they do not have permanent high income jobs. In the observations made in the library, it was witnessed that graduate students brought their children to the library. The low income families in the real sense are not a part of this clientele. Emily thinks that most of these families are concerned about the high cost of lost and damaged library materials. Transportation is another problem for these families. This situation is similar to Nespeca's (1995) findings; she points out that Head-Start families do not use public libraries because of limited time, and transportation problems.

Kelly points out the diversity among the families using library services. She thinks that although they have people from almost every group of the community, she reports that families from Middle East and Asia seem to be more involved in library programs compared to families from Middle and South American countries. During the visits made to the library it was observed that a lot Asian families were using the library extensively. They were participating in the programs, and checking out material s for their children. 


\section{Programs}

Kelly reports that Children's Department focuses heavily on birth through 3- year-old children, because according to the feedback they receive from Head Start teachers, by the time children get to three years, they are already behind and missed what they needed to have earlier. Preschool exploration center and infant-toddler programs are products of these kinds of feedbacks. The Department runs a program called "Lap Babies" for babies from birth through 12 months. Once a month, babies and their parents or caregivers are invited to this program which includes songs, games, like clap hands, touch the different parts of body with rhymes, and conversations with the babies. Another program called "Cruisers and Walkers" is for 12 to 24 months children. Again, this is a monthly program where similar activities as in Lap Babies are included. Unlike Lap Babies, some interactive but non-competitive plays, such as pee-ka-boo and finger-plays are employed in this program. Another interactive program for two year-olds (which is called "Tuneful Twos") is a little bit different from the previous two programs. In this program, music is one of the main attractions and singing songs with children and listening music is highly emphasized. For threes, fours, and fives, a movement and literature oriented program is employed. Reading books, doing story telling, doing crafts with children, and little acting are the main components of this program. Also, the Department employs special programs throughout the year; for example a character from children's picture books comes in his costumes or a famous children singer, author or storyteller is invited to the department. Yet other three programs called "Story Extravaganza", "Story/Craft Special" and "Preschool Story Series" are held regularly for 3-6 year-old preschool children. In these programs, they sing, watch movies, play finger games, listen to favorite stories and celebrate seasonal themes such as Halloween, Thanksgiving, and Christmas. A Story Extravaganza session subtitled "Visiting was observed. The topic was Thanksgiving and family visits. First, children sang along with a guitar player, then a short film was showed regarding turkeys, and then a storytelling session and finger play was the closing actions of the program. During the program, children were actively involved in all of the actions, they sang, played finger games, and listened carefully to the story. Christie (1995, p.24) states that "active involvement with stimulating environments provides a critical developmental foundation for all aspects of mental development, including literacy". $\mathrm{He}$ also explains that playing in environments where book, language and story are emphasized allows children to make a better sense of language and literacy. In that sense, it may be said that Children's Department has quality programs to facilitate children's emergent literacy development.

\section{Constraints}

Both participants agreed on the fact that money is the most important obstacle in terms of providing services to underserved clientele or better service to the current clientele. Kelly reported that the budget of Children's Department is allocated by administration of the board and usually the administration's priority is not children. She says that 
"there are times when we would like to do things particularly in early childhood area that I think may be the administration saying wait a minute this is what libraries ought to do, you know should we not be putting more money on the computers". To overcome this issue, on the other hand, they try to find alternative money resources such as getting money from the library foundation called "Friends of Library". Although the Library's budget comes from income and property taxes of the county, Children's Department gets most of their programming money from the Friends of the Library, not from the library's tax funds.

Kelly and Emily also agreed on staff shortage. Kelly reported that she would prefer to have an expert in early childhood who could work with designing and developing programs and staffing would be the first thing she would resolve if she had unlimited funds. Emily stated that they have to spend more money on materials and less money on personnel. She continued that they try to reach the most people with the most materials using few personnel because they want to spend less money on personnel.

Another shared issue is the library's outreach programs. Kelly expressed that library outreach is not a major concern of the administration because circulation statistics is going up and up but she would take library resources from the library someplace where they could present programs for those who never come to the library. Emily said library outreach was one of the important issues they were planning on improving in the future. Nespeca (1995) found that the parents demand library outreach programs and workshops about using the libraries. It seems that library outreach to low income or underserved people is a common problem in public library systems. Although taking library services to this clientele is very important, cost of these services is the most important obstacle for public libraries.

In brief, it seems that lack of financial resources is the major constraint that prevents the library from hiring more staff, employing a variety of programming, and doing a better job in library outreach services.

\section{Conclusion}

This study once again confirmed the role and importance of libraries for the community. Libraries' importance and responsibility comes from the fact that public libraries are free and open to everyone. They could be assumed to one of the few places for the low income families to access books, or audio visual materials. Considering the services, this library provides its maximum capacity within financial resources available. However, there is need to provide more outreach programs that could reach the clientele who never uses the services. In order to make libraries more attractive to this population, the libraries are in constant need for more financial resources and professional staff. To this end, there are some future plans prepared by the library administration. More funds could be obtained in governmental level through good programming, such as applying for grants or working in cooperation with non-governmental organizations. 
Considering the rapid growth of immigrant population in the area, the Library should take into consideration developing new programs to address the needs of limited or non-English speaking families' children. One way to this aim could be contacting and cooperating with libraries located in highly immigrant populated regions of the country.

Another important issue is the assessment and development of the programs. The programs offered by the library need to be updated and their efficiency needs to be constantly assessed. They should also be flexible to the changing needs of the population. To this end, trained and experienced children's librarians whose areas of specialty include early childhood education and child development should be hired.

Children's Department could also benefit from cooperation with child care providers. The child care providers could introduce the library services to their children and the libraries could send their staff to promote emergent literacy skills of the children in preschool centers. They also may exchange information regarding new trends in child development, early childhood education, or children's literature. Both ends could benefit from this cooperation.

\section{References}

American Library Association. (2007). 21st century literacy at your library. Retrieved November 10, 2007 from http://www.ala.org/work/literacybrochure.html

Anderson, J. and Matthews, R. (2000). Emergent storybook reading. Journal of Research in Reading, 22(3), 93-98.

Bowman, B., Donovan, S., and Burns M. S. (Eds.). (2001). Eager to learn: Educating our preschoolers. Washington, DC: National Academy Press. Retrieved December 16, 2007, from http://books.nap.edu/books/0309068363/html/index.html

CAPE. (2002). Monroe County Children Matter. Retrieved November 17, 2002 from http://www. indiana.edu/ ectesite/cape/monroe_county.htm

Census (2000). The City of Bloomington Census 2000 profile. Retrieved November 11, 2007 from http://www.city.bloomington.in.us/planning/lr/census/

Christie, J. F. (1995). Literacy play interventions: A review of empirical research. In S. Reifel (Ed.), Advances in Early Education and day care Vol. 6: Topics in Early Literacy, Teacher Preparation, and International Perspectives on Early Care, (pp. 3-28). Greenwich, CT: JAI Press.

Connecticut State Library (2007). Library Services and Technology Act State of Connecticut. Retrieved November 7, 2007 from http://www.cslib.org/lsta/5year.htm

Department of Education (2007a). Goals 2000: Educate America Act. Retrieved November 7 , 2007 from http://www.ed.gov/legislation/GOALS2000/TheAct/ 
Department of Education (2007b). Reading Excellence Act. Retrieved November 7, 2007 from http://www.ed.gov/inits/ FY99/1-read.html

Dowd, F. S. (1997). Evaluating the impact of public library story time programs upon the emergent literacy of preschoolers: A call for research. Public Libraries, 36(6), 346-358.

Fehrenbach, L. A., Hurford, D. P., Fehrenbach, C. R., and Brannock, R. G. (1998). Developing the emergent literacy of preschool children through a library outreach program. Journal of Youth Services in Libraries, 12(1), 40-45.

Kinney, M. S. (1996). A naturalistic inquiry into the effect of emergent literacy behavior on families in public housing communities. Unpublished PhD. thesis, University of Pittsburgh, Pittsburgh: PA.

Koehnecke, D. S. (2000). Increasing literacy through storytelling. Reading Improvement, 37(4), 187-189.

McKechnie, L. (1996). Opening the preschoolers' doors to learning: An ethnographic study of the use of public libraries by preschool girls. Unpublished PhD. thesis. University of Western Ontario, London: Ontario.

Merriam, S. B. (2001). Qualitative research and case study applications in education. San Francisco, CA: Jossey-Bass.

Morton, D. S. (2007). The Rhode Island READS Experience. Retrieved November 8, 2007 from http://www.nationalservice.org/research/fellows_reports/morton.pdf

Nespeca, S. M. (1995). Parental involvement in emergent literacy skills of urban Head Start children. Early Child Development and Care, 111, 153-180.

No Child Left Behind Act of 2001, Pub. L. No. 107-110.

Pankey, J. C. (2000). The benefits of reading aloud to preschool children. Unpublished master's thesis, Biola University, La Mirada: CA (ERIC Document Reproduction Service No. ED448866).

Patton, M. Q. (1985). Quality in qualitative research: Methodological principles and recent developments. Invited address to division Journal of the American Educational Research Association, Chicago, IL

Phillips, L. (1999). The role of storytelling in early literacy development. Retrieved December 6, 2007 from http://www.home.aone.net.au/stories/doc/childhd.htm

Public Libraries Association. (2007). Public Library Association and Association for Library Services to Children's preschool literacy initiative. Retrieved November 10, 2007 from http:// www.pla.org/projects/preschool/preschool.html

Roskos, K. A. and Neuman, S. B. (1994). Of scribbles, schemas, and storybooks; using literacy albums to document young children's literacy growth. Young Children, 49, 78-85. 
Senechal, M. and LeFevre, J. A. (2001). Storybook reading and parent teaching: Links to language and literacy development. New Directions for Child and Adolescent Development, 92, 3952.

Shonkoff, J. P. and Phillips D. A. (2000). From neurons to neighborhoods: The science of early childhood development. Washington, DC: National Academy Press.

Storch, S. A. and Whitehurst, G. J. (2001). The role of family and home in the literacy development of children from low-income backgrounds. New Directions for Child and Adolescent Development, 92, 53-71.

Sulzby, E. (1991). Emergent literacy. In Rebecca Barr (Ed.), Handbook of Reading Research (pp.727-753). Mahwah, NJ: L. Erlbaum Associates.

Teale, W. H. (1995). Public libraries and emergent literacy: Helping set the foundation for school success. In B. F. Immroth and V. Ash-Geisler (Eds.), Achieving school readiness: Public libraries and national education goal no.1 (pp. 113-133). Chicago, IL: American Library Association.

The Association for Library Service to Children. (2007). Born to read: A project fact sheet. Retrieved November 2, 2007 from http://www.ala.org/alsc/born.html 
